\title{
Microbial Contamination and Detection of Antibacterial Activity of Syzygium aromaticum against Food Borne Pathogens
}

\author{
Jubaida Binta Jamal, Tasnia Ahmed and Md. Aftab Uddin* \\ Department of Microbiology, Stamford University Bangladesh, 51 Siddeswari Road, Dhaka-1217, Bangladesh.
}

\begin{abstract}
This study was undertaken to find out the presence of contaminating microorganisms in commonly available Syzygium aromaticum samples collected from different areas of Bangladesh and also to evaluate the antibacterial traits of these Syzygium aromaticum samples against food born pathogens. Total viable bacterial count (TVBC) was determined on nutrient agar and for the isolation of specific microorganisms different selective media were used. Crude, ethanol, methanol, hot water and cold water extracts of the samples were prepared for analysing their antibacterial activity using the agar well diffusion method. Furthermore, the minimum inhibitory concentration (MIC) of the crude extracts was determined. TVBC was found between $10^{4}$ to $10^{6} \mathrm{cfu} / \mathrm{g}$. None of these samples showed the presence of fungus. Staphylococcus spp. was present almost in all the samples between $10^{4}$ to $10^{6} \mathrm{cfu} / \mathrm{g}$ while Bacillus spp. was noticed only in one sample. In vitro antibacterial activity of the crude, methanolic and ethanolic extracts of the samples was found to be effective mostly against Escherichia coli, Klebsiella spp., Listeria spp., Pseudomonas spp. and Bacillus spp. On the contrary, hot water extracts of only two samples showed antibacterial property against Pseudomonas spp., Listeria spp. and Klebsiella spp. MIC was confirmed by using 96 well plate methods and the minimum inhibitory concentration was between 11.75 to $94 \mathrm{mg} / \mathrm{ml}$.
\end{abstract}

\section{Introduction}

For many centuries spices are used by all countries to augment flavour and aroma in different types of food and in treatment of clinical ailments ${ }^{1}$. Antibiotics supply the main root for the treatment of microbial infections ${ }^{2}$. Microorganisms have become resistant to many antibiotics due to increased use of drugs. So, it has become essential to find out new antimicrobial agents ${ }^{3,4}$.

The most common bacteria causing food-borne illness are Escherichia coli, Staphylococcus, Salmonella spp., Listeria monocytogenes, Clostridium botulinum, Vibrio vulnificus, Vibrio parahaemolyticus and others ${ }^{5,6}$. Syzygium aromaticum may be contaminated because of the surroundings under which they were cultivated and harvested. Contaminated $S$. aromaticum have been reported for the cause of certain food-borne illnesses and spoilage ${ }^{7}$. Therefore, $S$. aromaticum sometime pose health trouble because they are often added to foods without supplementary processing or are eaten uncooked ${ }^{8}$.

Cloves of Syzygium aromaticum are the pungent dried flower buds of a tree in the family Myrtaceae. Cloves are local to Indonesia and used as a spice in cuisines worldwide ${ }^{9}$. It is also used as a carminative, rubefacient and serves as a preservative in herbal recipes, signifying possible antimicrobial property $5,10,11$. S. aromaticum contain compounds like gallotannins, triterpenes, flavonoids, and phenolic acids ${ }^{12,13}$.
In Bangladesh, although a lot of works has been conducted based on herbal plants and medicines, there is a little information on the sources of contamination and antibacterial activity of cloves. Based on this consideration the current study was designed to detect the microbial contamination and detection of antibacterial activity of Syzygium aromaticum collected from various parts of Bangladesh.

\section{Methods \& materials}

Study area, sampling and sample processing

Ten Syzygium aromaticum samples were randomly collected from Comilla, Reazuddin Bazar (Chittagong), Pahartali (Chittagong), Shantinagor (Dhaka), Gazipur, Ashulia, Tongi, Uttara (Dhaka), Rajshahi and Netrokona during August 2015-November 2015 following the standard protocol ${ }^{15,16}$. For the detection of contaminating bacteria and fungi, $10 \mathrm{~g}$ of each sample was homogenized with $90 \mathrm{~mL}$ normal sterile saline and serially diluted up to $10^{-5}$.

\section{Microbiological analysis}

For each of the samples, $0.1 \mathrm{~mL}$ from the dilution $10^{-2}$ and $10^{-5}$ were introduced on to the Nutrient agar (Hi-Media Laboratories Pvt. Ltd., India) and sabouraud dextrose agar (Hi-Media Laboratories Pvt. Ltd., India) for the enumeration of total viable bacteria and fungi, respectively. Consequently, different selective

*Corresponding author:

Md. Aftab Uddin, Assistant Professor, Department of Microbiology, Stamford University Bangladesh, 51 Siddeswari Road, Dhaka-1217,

Tel: +880 8355626, +8808355596 ext. 478, Cell: +8801817581793,E-mail: aftab_mb12@yahoo.com 
media such as MacConkey agar (Hi-Media Laboratories Pvt. Ltd., India), Mannitol salt agar (Merck Specialities Pvt. Ltd, Mumbai, India), Cetrimide agar (Hi-Media Laboratories Pvt. Ltd., India), Starch agar (manually produced by using peptone, beef extract, bacterial agar and starch), Salmonella Shigella agar (SS Agar), and Thiosulfate-citrate-bile salts-sucrose (TCBS) agar (Hi-Media Laboratories Pvt. Ltd., India) were used for the detection of coliforms, Staphylococcus spp. Pseudomonas spp, Bacillus spp., Salmonella spp., Shigella spp. and Vibrio spp. respectively ${ }^{16}$. Alkaline Peptone Water (APW) was used to enrich Vibrio spp. and Selenite Cystine Broth (SCB) was used to enrich Salmonella spp. and Shigella spp. for 3 hours. All the inoculated plates were incubated at $37^{\circ} \mathrm{C}$ for 24 hours except Sabouraud Dextrose agar plates, which were incubated at $25^{\circ} \mathrm{C}$ for 48 hours ${ }^{17}$.

\section{Crude extraction}

$3.33 \mathrm{~g}$ of dried and blended sample were soaked in $10 \mathrm{~mL}$ of normal sterile saline (maintaining the ration of $25 \mathrm{~g}$ of sample with $75 \mathrm{~mL}$ of normal saline $)^{17}$.

\section{Hot water extraction}

$5 \mathrm{~g}$ Dried sample were soaked with $45 \mathrm{~mL}$ of sterile distilled water (maintaining the ration of $10 \mathrm{~g}$ sample with $90 \mathrm{~mL}$ of the water) and boiled at $100{ }^{\circ} \mathrm{C}$ for 10 minutes in Durham's bottle (Schott Duran, Germany) (i.e., distilled water extract) and kept in shaking water bath (Daihan Scientific Co., Ltd, Korea, Model No-WSB-30) at $130 \mathrm{rpm} / \mathrm{min}$ for $24 \mathrm{~h}$ at $20^{\circ} \mathrm{C}$. Samples were aseptically filtered through sterile Whatman No 1 filter paper (Hangzhou Xinhua Paper Industry Co., Ltd., Hangzhou, China). Then the liquid portion was collected ${ }^{18}$.

\section{Solvent extraction}

Subsequently, $5 \mathrm{~g}$ of the dried clove powder of each sample were added with $45 \mathrm{~mL}$ of ethanol and methanol(maintaining the ratio of $10 \mathrm{~g}$ sample with $90 \mathrm{~mL}$ ethanol and methanol) in Durham's bottle and were kept in shaking water bath (WSB-30, Korea) at $130 \mathrm{rpm} / \mathrm{min}$ for 24 hours at $20^{\circ} \mathrm{C}$. After filtration the fluid section was collected ${ }^{19,20,21}$.

Antimicrobial assay

Modified agar well diffusion method was followed using MuellerHinton agar (MHA) plates (Oxoid Ltd., Basingstoke, Hampshire, England). The suspension of Escherichia coli (E. coli), Pseudomonas spp., Salmonella spp., Listeria spp., Vibrio spp., Klebsiella spp., Staphylococcus spp. and Bacillus spp. were introduced on to the wells $(8 \mathrm{~mm}$ ) of the MHA media. Then 100 $\mu l$ of the samples (crude extract, Distilled water extract, autoclaved hot water extract, ethanol extract, methanol extract) at a concentration of $11.1 \mathrm{mg} / \mathrm{ml}$ were introduced. Besides absolute ethanol (Merck Specialities Pvt. Ltd, Germany), methanol (Merck Specialities Pvt. Ltd, Germany) and normal sterile saline as negative control were applied. Antibiotic disc of gentamicin $10 \mu \mathrm{g}$ (Oxoid Ltd., Basingstoke, Hampshire, England) was used as a positive control. Plates were incubated at $37{ }^{\circ} \mathrm{C}$ for $12-18 \mathrm{~h}$, and were examined for the determination of zone of inhibitions $(\mathrm{mm})^{17,22,23}$.

\section{Determination of Minimal Inhibitory Concentration (MIC)}

For the detection of antibacterial activity of clove, the minimum inhibitory concentration (MIC) or broth microdilution assay was demonastrated $^{4,24}$. An aliquot of $10 \mu \mathrm{L}$ of each bacterial culture (ovenight growth, $\sim 12$ hours) was inoculated into the appropriately labeled sterile tubes containing Mueller Hinton broth (MHB) (Oxoid Ltd, England) at the turbidity adjusted with $0.5 \mathrm{McFarland}$ standard. Afetrward different volumes of the samples ( $16 \mu \mathrm{L}, 32 \mu \mathrm{L}, 64 \mu \mathrm{L}, 128 \mu \mathrm{L}$, and $256 \mu \mathrm{L}$ ) were introduced to make a total volume of $300 \mu \mathrm{L}$. After incubation at $37^{\circ} \mathrm{C}$ for 24 hours all the tubes were observed and recorded the lowest concentration $(\mathrm{mg} / \mathrm{mL})$ of each sample in which the bacterial cell was found to be retarded and considered as the MIC value $2,15,24$.

\section{Results}

Microbial Analysis of Syzygium aromaticum (clove) samples:

In the present study, TVBC was observed within the range of $3 \times 10^{4}$ to $5.3 \times 10^{7} \mathrm{cfu} / \mathrm{g}$. Among the specific isolates, coliform, Salmonella, Vibrio, Pseudomonas and fungi were not detected in any of the clove samples. Staphylococcus spp. was the most prevalent bacteria, found almost in all samples between $1 \times 10^{4}$ to $1.08 \times 10^{6} \mathrm{cfu} / \mathrm{g}$ (Table 1). Bacillus spp. $\left(1.83 \times 10^{7)}\right)$ was only found in sample collected from Reazuddin Bazar.

Table 1. Microbiological analysis of Syzygium aromaticum (clove) samples

\begin{tabular}{llcc}
\hline $\begin{array}{l}\text { Sample } \\
\text { No. }\end{array}$ & Sample & TVBC & Staphylococcasspp. \\
\hline 1 & Comilla & $9.0 \times 10^{5}$ & $4 \times 10^{5}$ \\
2 & Reazuddin bazar(Chittagong) & $5.3 \times 10^{7}$ & 0 \\
3 & Pahartali (Chittagong) & $3 \times 10^{4}$ & 0 \\
4 & Shantinagor (Dhaka) & $1 \times 10^{6}$ & 0 \\
5 & Gazipur & $2.62 \times 10^{6}$ & $1 \times 10^{4}$ \\
6 & Ashulia & $1.01 \times 10^{6}$ & $1.0 \times 10^{5}$ \\
7 & Tongi & $2 \times 10^{6}$ & $2.4 \times 10^{5}$ \\
8 & Uttara (Dhaka) & $2 \times 10^{6}$ & $1.08 \times 10^{6}$ \\
9 & Rajshahi & $4 \times 10^{6}$ & $1.1 \times 10^{5}$ \\
10 & Netrokona & $5 \times 10^{6}$ & $3 \times 10^{5}$ \\
\hline
\end{tabular}

Maximum limit (cfu/g) of microorganisms in spices: (According to ICMSF: 1998$)^{25}$

- total viable bacterial count (TVBC): $10^{6} \mathrm{cfu} / \mathrm{g}$

- fungi: $10^{4} \mathrm{cfu} / \mathrm{g}$

- Coliforms and E. coli: $10^{3} \mathrm{cfu} / \mathrm{g}$

Antibacterial activity of Syzygium aromaticum (Clove) extracts (crude Extraction):

Crude extracts of sample nos. 1, 9 and 10 showed antibacterial activity against $E$. coli. No activity of the crude extracts was found against Salmonella spp. and Pseudomonas spp. Similar types of zone of inhibition was observed for Listeria spp., Vibrio spp. and Staphylococcus spp. whereas variable result was noticed against Bacillus spp. (Table 2). 
Table 2. Antibacterial activity of crude extraction: zone of inhibition ( $\mathrm{mm}$ )

\begin{tabular}{lcccccc}
\hline Sample No. & E. coli & Staphylococcus spp. & Bacillus spp. & Vibrio spp. & Klebsiella spp. & Listeria spp. \\
\hline 1. Comilla & 10 & 13 & 0 & 12 & 18 & 13 \\
2. Reazuddin bazar(Chittagong) & 0 & 12 & 0 & 11 & 17 & 12 \\
3. Pahartali (Chittagong) & 0 & 16 & 11 & 12 & 18 & 10 \\
4. Shantinagor (Dhaka) & 0 & 13 & 12 & 12 & 17 & 10 \\
5. Gazipur & 0 & 12 & 14 & 11 & 15 & 10 \\
6. Ashulia & 0 & 11 & 13 & 11 & 0 & 13 \\
7. Tongi & 0 & 0 & 11 & 0 & 0 & 10 \\
8. Uttara (Dhaka) & 0 & 12 & 0 & 0 & 14 & 12 \\
9. Rajshahi & 10 & 13 & 0 & 0 & 18 & 12 \\
10. Netrokona & 10 & 0 & 0 & 0 & 17 & 11 \\
11. Positive control (Gentamicin) & 17 & 15 & 14 & 14 & 18 & 17 \\
12. Negative Control (Normal saline) & 0 & 0 & 0 & 0 & 0 & 0 \\
\hline
\end{tabular}

The results of antibacterial activities (Ethanol, Methanol and Hot water extraction):

By analyzing the results, mostly Syzygium aromaticum has antibacterial activity against $E$. coli, Klebsiella spp. Listeria spp. and Pseudomonas spp, Bacillus spp. in comparison to the clear zone of the positive control Gentamicin (10 1/4g) as standard $(\geq 15 \mathrm{~mm})^{26}$. Antibacterial activity was found for three samples against Vibrio spp. and little was shown against Staphylococcus spp. and Salmonella spp. (Table 3).

Table 3. Bacterial isolates susceptible against various extracts of Syzygium aromaticum Collected from different areas of Bangladesh

\begin{tabular}{|c|c|c|c|c|}
\hline \multirow{2}{*}{$\begin{array}{l}\text { Sample } \\
\text { No. } \\
\end{array}$} & \multirow[t]{2}{*}{ Sample } & \multicolumn{3}{|c|}{ Bacterial isolates susceptible (zone of inhibition in $\mathrm{mm}$ ) against various extracts of Syzygium aromaticum } \\
\hline & & Ethanol extraction & Methanol extraction & Hot water extraction \\
\hline 1 & Comilla & $\begin{array}{l}\text { E. coli }(21 \mathrm{~mm}) \text {, Staphylococcus } \\
\text { spp. }(20 \mathrm{~mm}), \text { Vibrio } \mathrm{spp} .(18 \mathrm{~mm}) \text {, } \\
\text { Pseudomonas spp. }(17 \mathrm{~mm}), \\
\text { Listeria } \text { spp. }(18 \mathrm{~mm})\end{array}$ & $\begin{array}{l}\text { E. coli }(20 \mathrm{~mm}), \text { Klebsiella } \\
\text { spp. }(15 \mathrm{~mm}) \text {, Staphylococcus } \\
\text { spp. }(18 \mathrm{~mm}) \text {, Vibrio } \text { spp. } \\
(20 \mathrm{~mm}), \text { Pseudomonas } \mathrm{spp} \\
.(18 \mathrm{~mm}), \text { Listeria } \text { spp. } \\
(19 \mathrm{~mm})\end{array}$ & \\
\hline 2 & $\begin{array}{l}\text { Chittagong } \\
\text { (Reazuddin } \\
\text { bazar) }\end{array}$ & $\begin{array}{l}\text { E. coli }(18 \mathrm{~mm}), \text { Pseudomonas spp. } \\
(16 \mathrm{~mm})\end{array}$ & $\begin{array}{l}\text { Klebsiella spp. }(20 \mathrm{~mm}) \\
\text { Listeria } \text { spp. }(16 \mathrm{~mm})\end{array}$ & \\
\hline 3 & $\begin{array}{l}\text { Chittagong } \\
\text { (pahartali): }\end{array}$ & $\begin{array}{l}\text { Klebsiella spp. }(23 \mathrm{~mm}), \text { Bacillus } \\
\text { spp. }(15 \mathrm{~mm}), \text { Pseudomonas } \mathrm{spp} \\
.(19 \mathrm{~mm})\end{array}$ & $\begin{array}{l}\text { Klebsiella } \text { spp. }(23 \mathrm{~mm}) \text {, } \\
\text { Pseudomonas } \mathrm{spp} .(19 \mathrm{~mm}) \text {, } \\
\text { Listeria } \text { spp. }(20 \mathrm{~mm})\end{array}$ & $\begin{array}{l}\text { Klebsiella } \mathrm{spp} .(17 \mathrm{~mm}) \\
\text { Listeria } \text { spp. }(17 \mathrm{~mm})\end{array}$ \\
\hline 4 & $\begin{array}{l}\text { Dhaka } \\
\text { (Shantinagar) }\end{array}$ & & E. coli $(15 \mathrm{~mm})$ & \\
\hline 5 & Gazipur & $\begin{array}{l}\text { E. coli }(19 \mathrm{~mm}), \text { Listeria } \\
\text { spp. }(15 \mathrm{~mm})\end{array}$ & E. coli $(19 \mathrm{~mm})$ & \\
\hline 6 & Ashulia (Dhaka) & $\begin{array}{l}\text { E. coli }(19 \mathrm{~mm}), \text { Bacillus spp. } \\
(15 \mathrm{~mm})\end{array}$ & & \\
\hline 7 & Tongi & Vibrio spp. (15mm) & $\begin{array}{l}\text { E. coli }(16 \mathrm{~mm}), \text { Vibrio spp. } \\
(15 \mathrm{~mm})\end{array}$ & \\
\hline 8 & Uttara (Dhaka) & $\begin{array}{l}\text { E. coli }(24 \mathrm{~mm}) \text {. Bacillus spp. } \\
\text { (17mm), Vibrio spp. }(16 \mathrm{~mm}) \text {, } \\
\text { Pseudomonas spp. }(22 \mathrm{~mm}) \text {, } \\
\text { Listeria } \text { spp. }(17 \mathrm{~mm})\end{array}$ & $\begin{array}{l}\text { E.coli }(23 \mathrm{~mm}), \text { Bacillus } \mathrm{spp} . \\
(15 \mathrm{~mm}), \text { Pseudomonas } \mathrm{spp} . \\
(23 \mathrm{~mm}), \text { Listeria } \text { spp. }(21 \mathrm{~mm})\end{array}$ & Pseudomonas spp. (17mm) \\
\hline 9 & Rajshahi & $\begin{array}{l}\text { E.coli }(22 \mathrm{~mm}), \text { Klebsiella } \mathrm{spp} . \\
(19 \mathrm{~mm}), \text { Listeria } \mathrm{spp} .(19 \mathrm{~mm})\end{array}$ & $\begin{array}{l}\text { Bacillus spp. (18mm), } \\
\text { Staphylococcus spp. }(16 \mathrm{~mm}) \text {., } \\
\text { Salmonella spp. }(15 \mathrm{~mm}), \\
\text { Vibrio spp. }(20 \mathrm{~mm}), \text { Listeria } \\
\text { spp. (25mm) }\end{array}$ & \\
\hline 10 & Netrokona & $\begin{array}{l}\text { E.coli }(15 \mathrm{~mm}), \text { Klebsiella } \mathrm{spp} . \\
(15 \mathrm{~mm}), \text { Listeria } \mathrm{spp} .(20 \mathrm{~mm})\end{array}$ & $\begin{array}{l}\text { E.coli }(16 \mathrm{~mm}), \text { Klebsiella } \\
\text { spp. }(18 \mathrm{~mm}), \text { Bacillus } \mathrm{spp} . \\
(15 \mathrm{~mm}), \text { Listeria } \text { spp. } \\
(20 \mathrm{~mm})\end{array}$ & \\
\hline
\end{tabular}


Table 4. Determination of the minimum inhibitory concentration of the crude extracts $(\mathrm{mg} / \mathrm{ml})$

\begin{tabular}{|c|c|c|c|c|c|c|c|c|}
\hline Sample & $\begin{array}{c}\text { Klebshiella } \\
\text { spp. }\end{array}$ & $\begin{array}{l}\text { Vibrio } \\
\text { spp }\end{array}$ & $\begin{array}{l}\text { Pseudomona } \\
\text { sspp. }\end{array}$ & $\begin{array}{c}\text { Staphylococcus } \\
\text { spp. }\end{array}$ & $\begin{array}{l}\text { Bacillus } \\
\text { spp. }\end{array}$ & E. coli & $\begin{array}{l}\text { Salmonella } \\
\text { spp. }\end{array}$ & $\begin{array}{c}\text { Listeria } \\
\text { spp. }\end{array}$ \\
\hline Sample-1 & 23.5 & 23.5 & 23.5 & 23.5 & 23.5 & 23.5 & 23.5 & 23.5 \\
\hline Sample-3 & 23.5 & 23.5 & 23.5 & 23.5 & 23.5 & 23.5 & 94 & 23.5 \\
\hline Sample-4 & 23.5 & 23.5 & 23.5 & 23.5 & 11.75 & 11.75 & 23.5 & 23.5 \\
\hline Sample-7 & 94 & 47 & 47 & 47 & 47 & 47 & 47 & 47 \\
\hline Sample-8 & 94 & 94 & 94 & 94 & 47 & 47 & 47 & 47 \\
\hline Sample-9 & 47 & 47 & 47 & 47 & 94 & 94 & 94 & 94 \\
\hline Sample-10 & 94 & 47 & 47 & 94 & 94 & 94 & 94 & 94 \\
\hline
\end{tabular}

In each experiment, both the positive control Gentamicin $(10 \mu \mathrm{g})$ and the negative control of normal saline, ethanol and methanol were maintained. In all the cases, Gentamicin produced zone of inhibition around $15-18 \mathrm{~mm}$ against all the laboratory isolates and the negative controls didn't show zone of inhibition at all.

\section{Minimum Inhibitory Concentration (MIC) assay of the crude} extracts of the samples:

In this study, the MIC for the crude extract of various samples was determined. Unlike the results obtained from agar well diffusion method of the crude extracts of samples, the MIC study also revealed the inhibition of the growth for all the eight laboratory isolates. Interestingly MIC for the sample nos. 1-4 showed the growth retardation on an average of $23.5 \mathrm{mg} / \mathrm{ml}$. On the other hand, for sample nos. 5-10 minimum inhibitory concentrations obtained was between of 47 to $94 \mathrm{mg} / \mathrm{ml}$. Noticeably, E. coli and Bacillus spp. was inhibited at the concentration of $11.75 \mathrm{mg} / \mathrm{ml}$ by the sample no. 4 .

\section{Discussions}

Medicinal plants play a vital role for the development of new drugs. Besides production of synthetic drugs, the biopharma industries in Bangladesh like Square Pharma and others are producing herbal medicines. During harvesting Syzygium aromaticum may come in contact with various types of microorganisms which may cause certain food-borne illnesses and spoilage ${ }^{7}$. Therefore current study was designed for analysing the microbiological contamination of Syzygium aromaticum (clove) samples collected from various areas of Bangladesh and also to determine their antibacterial activity against eight food borne pathogens.

Previous studies on the microbiology of spices have demonstrated contamination of microorganisms, including total heterotrophs, Bacillus cereus, Clostridium perfringens, Escherichia coli, Salmonella and toxigenic moulds ${ }^{7}$ (ref). From the Table 1 it was observed that a substantial amount of total viable bacteria were present in almost all the samples. Staphylococcus spp. were present in all the samples. As it is known that Staphylococcus spp. is a normal flora of skin, the sample was possibly contaminated from skin flora (Table 1). Sample no. 2 contained Bacillus spp. One of the major reasons for this may be due to the contact of the sample with soil (Table 1) ${ }^{27}$. Sometime unprocessed clove is consumed as mouth freshener so it should not contain the microorganisms. This finding was not correlated with the findings of Parveen et al., (2014) ${ }^{28}$ who beside detecting TVBC also found the presence of yeast, mould and coliform.

Ethanolic extract of various samples gave clear zone of inhibition against most of the laboratory isolates. The clear zone was better for mainly Listeria spp., E. coli, Klebsiella spp. and Bacillus spp. In case of methanolic extract better results were recorded against E. coli, Listeria spp., Pseudomonas spp. and Klebsiella spp. On the other hand Staphylococcus spp. and Vibrio spp. were found to be the most resistant isolate against both the methanolic and ethanolic extracts of clove samples ${ }^{29}$. In case of methanolic extraction better clear zones were establish than ethanol extraction. From Result from Pandey et al., (2011) ${ }^{3}$ showed that extraction with ethanol against Staphylococcus aureus gave 20 $\mathrm{mm}$ inhibition zone and Pseudomonas aeruginosa give $18 \mathrm{~mm}$ zone of inhibition but no zone of inhibition was found against $E$. coli for both ethanol and methanol extraction.

As there was significant antibacterial activity found in agar diffusion assay, the minimum inhibitory concentration (MIC) of the clove extract for all the organisms were determined. The lowest MIC (11.75 mg/ml) was achieved for the sample no 4 and the maximum $(94 \mathrm{mg} / \mathrm{ml})$ concentration was found for sample nos. 4, 6, 8, 9 and 10. Interestingly all the tested laboratory isolates were found to be sensitive within this range. There hasn't been much previous report on MIC regarding the clove samples, although there are some studies on herbal medicine and related products. In a study conducted by Sharmin et al., (2014) ${ }^{24}$ on herbal medicine showed the MIC was $10 \mathrm{mg} / \mathrm{ml}$ for the isolates which was pretty much similar to that of the lowest MIC (11 mg/ $\mathrm{ml}$ ) recorded in this study.

\section{Conclusions}

In vitro studies have revealed Syzygium aromaticum to have bacteriostatic, bactericidal property. The result of the antibacterial 
traits of the samples reflected in this study strongly indicates the huge potentiality of Syzygium aromaticum (cloves) as a good candidate to be used as a medicinal plant to treat various food borne diseases caused by the pathogenic microorganisms. However further studies are needed to better estimate the accurate efficiency of the extracts as the antimicrobial agent. Besides as Syzygium aromaticum (cloves) are sometimes taken raw for various purposes, better hygienic approaches should be taken both at the consumer and the producer level to avoid any food borne infection.

\section{References:}

1. Kumar Y, Agarwal S, Srivastava A, Kumar S, Agarwal G and Khan MZA. 2014. Antibacterial activity of Clove (Syzygium aromaticum) and Garlic (Allium sativum) on different pathogenic bacteria. Int. J. of Pure \& App. BioSci. 2(3): 305-311.

2. Abdullah BH, Hatem SF and Jumma W. 2015. Comparative study of antibacterial activity of clove and rosemary essential oils on multidrug resistant bacteria. J. of Pharma. \& BioSci. 3(1): 18-22.

3. Pandey A, Singh P. 2011. Antibacterial activity of Syzygium aromaticum (clove) with metal ion, effect against food borne pathogens. Asian J. of Plant Sci. \& Rec. 1(2):69-80)

4. Hammer KA, Carson CF and Riley TV . 2004. Antifungal effects of Melaleucaalternifolia (tea tree) oil and its components on Candida albicans, Candida glabrataand Saccharomyces cerevisia. J. Anti-microb. Chemo. 53: 1081-1085.

5. Takeda J., Silva SD, Muthuraman P, Rahman, SM and Lotje K. 2008. Spices in Sri Lanka, India and Bangladesh with Special Reference to the Usages and Consumptions. Bulletin of Faculty of Agriculture, Saga University. 93: 1-25.

6. Mishra R.P. and Kalyani S. 2014. Antimicrobial activities of SyzigiumaromaticumL. (Clove). Int. Rec. J. of BioSci.

7. Ahene R, Odamtten G and Owusu E. 2011. Fungal and bacterial contaminants of six spices and spice products in Ghana. African J.of Env. Sci. \& Tech. 5(9): 633-640.

8. Colak H, Bingol E, Hampikyan H and Nazli B. 2006. Determination of afla toxin contamination in red-scaled, red and black pepper by ELISA and HPLC. J. of Food \& Drug Anly. 14(3): 292-296.

9. Barakat H. 2014. Composition, Antioxidant, Antibacterial Activities and Mode of Action of Clove (SyzygiumaromaticumL.) Buds Essential Oil. Bri. J. of App. Sci. \& Tech. 4(13): 1934-1951.

10. Chaieb KH, Hajlaoui T, Zmantar KAB, Nakbi M, Rouabhia K, Mahdouani and Bakhrouf A . 2007. The chemical composition and biological activity of essential oil, Eugenia cryophyllata (SyzygiumaromaticumL. Myrtaceae), Phytotherapy Research. Wiley Int. Sci. 21(6): 501-506.

11. Singh N, Singh RK, Bhunia AK and Stroshine RL. 2002. Efficacy of chlorine dioxide, ozone, and thyme essential oil or a sequential washing in killing Escherichia coli $\mathrm{O} 157: \mathrm{H} 7$ on lettuce and baby carrots. Lebensmittel- Wissenschaft and -Tech. 35: 720-729.

12. Mahfuzul MH, Bari ML, Vijay K. Juneja, and Kawamoto S. 2008. Antimicrobial activity of clove and cinnamon extract against food born pathogens and bacteria with their essential oils. Rep. Natl. Food Res. 72: 9-21.
13. Gutierrez J, Barry-Ryan C, and Bourke P. 2009. Antimicrobial activity of plant essential oils using food model media: Efficacy, synergistic potential and interactions with food components. Food Microbiol. 26(2): 142-150.

14. Nascimento GGF, Locatelli J, Freitas PC, Silva JL. Dec. 2000. Antibacterial activity Of plant extract and phytochemicals on antibiotic resistant bacteria. Braz. J. of Microbiol. 31: 1678-4405.

15. Asmaa A. and Alharbi. October 2017. Antibacterial Activities of Syzygium aromaticum oil against Local Clinical Pathogenic Bacteria. Int. J. of Inno. Studies in Sci. Eng. Tech. 3(10): 2455-4863.

16. Branan B, Butcher J, and Olsen L. 2007. Using Ozone in Organic Chemistry Lab: The Ozonolysisof Eugenol. J. of Che. Edu. 84:1979-1981.

17. Sharmin M, Das KK, Acharjee M. 2014Estimation of microbiological propagation and antimicrobial traits of the frequently accessible flowers. Stamford Journal of Microbiology. 4(1): 19-23.

18. Selvamohan T, Ramadas V and Kishore SS. 2012. Antimicrobial activity of selected medicinal plants against some selected human pathogenic bacteria. Adv. App. Sci. Res. 3(5): 3374-3381.

19. Ruban P and Gajalakshmi K. 2012. In vitro antibacterial activity of Hibiscus rosa-sinensisflower extract against human pathogens. Asian Pac. J. Trop. Biomed. 2(5): 399-403.

20. Sejal R and Priya N. 2012. Evaluation of antimicrobial activity of Hibiscus rosa-sinensis. J. Pharm. Res. 5(6): 3318-3320.

21. Arullappan S, Zakaria $Z$ and Basri DF. 2009. Preliminary screening of antibacterial activity using crude extracts of Hibiscus rosasinensis, Trop. Life Sci Res. 20(2): 109-118.

22. Hussain A, Wahab S, Zarin I and Hussain MDS. 2010. Antibacterial activity of the leaves of Cocciniaindica (W. and A) of India. Adv. Biol. Res. 4(5): 241-248.

23. Sen A and Batra A. 2012.Evaluation of antimicrobial activity of different solvent extracts of medicinal plant: Meliaazedarach L. Int J. Curr Pharm Res. 4(2): 67-73.

24. Sharmin M, Nur IT, Acharjee M, Munshi SK, and Noor R. 2014 Dec 15 .Microbiological profiling and the demonstration of in vitro anti-bacterial traits of the major oral herbal medicines used in Dhaka Metropolis Springer plus. 2014; 3: 739. Published online doi: 10.1186/2193-1801-3-739.

25. ICMSF. 1998. Microorganisms in Foods. Sampling for Microbiological Analysis: Principles and Specifi c Applications, $2^{\text {nd }}$ edn. University of Toronto Press, Toronto.

26. Bassiri DR. Antibiotic sensitivity testing. Dept. Of Biology, University of Pennsylvania. BIOL 275.

27. Chaieb KH, Hajlaoui T, Zmantar KAB, Nakbi M, Rouabhia K, Mahdouani and Bakhrouf A .2007. The chemical composition and biological activity of essential oil, Eugenia cryophyllata (SyzygiumaromaticumL. Myrtaceae), Phytotherapy Research. Wiley InterSci. 21(6): 501-506.

28. Parveen S, Das S, Begum A, Sultana N, Hoque M and Ahmad I. 2014. Microbiological quality assessment of three selected spices in Bangladesh. Int. Food Res. J. 21(4): 1327-1330

29. Joe MM, Jayachitra J and Vijayapriya M. 2009. Antimicrobial activity of some common spices against certain human pathogens. J. of Medi. Plants Res. 3(11): 1134-1136. 